\title{
Assessment of the efficacy of a program to improve the social communication and behavior of young children with autism spectrum disorders
}

\author{
María del Sol Fortea, María Olga Escandell y José Juan Castro \\ Universidad de las Palmas de Gran Canaria, España
}

\begin{abstract}
Numerous studies reveal the benefits of early intervention for the adequate development of children with autism spectrum disorders (ASD). Most of the interventions designed for people with ASD focus exclusively on a sole methodology. This study proposes a Combined Early Intervention Program (hereafter CEIP) using different methodologies with scientific evidence: Early Intensive Behavioral Interventions (EIBI), Early Start Denver Model (DENVER), spatial-temporal organization (TEACCH), augmentative communication systems (the Picture Exchange Communication System-PECS—, Total Communication Program, Picture Communication Symbols-PCS), behavioral strategies, and training of the parents. This CEIP contemplates intervention in areas that are typically affected in ASD: socialization, communication, symbolization, and behavioral flexibility, producing considerable improvement in the children's behavior, decreasing problem behaviors and improving social communication.

Keywords: Applied behavioral analysis; Augmentative communication systems; Denver model; Early intervention; Intervention program; TEACCH methodology.
\end{abstract}

\section{Evaluación de la eficacia de un programa para mejorar la comunicación social y el comportamiento en jóvenes con trastornos del espectro autista}

\begin{abstract}
Resumen
Numerosos estudios ponen de manifiesto los beneficios de la atención temprana para la buena evolución de los niños con trastornos del espectro autista (TEA). La mayoría de las intervenciones diseñadas para personas con TEA se centran en una única metodología exclusivamente. Este estudio plantea un Programa de Intervención Temprana Combinando (en adelante CEIP) empleando diferentes metodologías con evidencia científica: Early Intensive Behavioral Interventions (EIBI), Early Start Denver Model (DENVER), organización espaciotemporal (TEACCH), sistemas aumentativos de comunicación (PECS, Comunicación Total, SPC), estrategias conductuales y entrenamiento a padres. Este CEIP contempla la intervención sobre las áreas típicamente afectadas en TEA: socialización, comunicación, simbolización y flexibilidad comportamental, repercutiendo en una mejora significativa del comportamiento de los niños, reduciendo las conductas problema y mejorando la comunicación social.
\end{abstract}

Palabras clave: Análisis de conducta aplicado; Atención temprana; Metodología TEACCH; Modelo Denver; Programa de intervención; Sistemas aumentativos de comunicación.

Correspondencia con los autores: mariaolga.escandell@ulpgc.es

Recibido 25 de Junio de 2015. Revisado 15 de Julio de 2015. Aceptado 17 de Julio de 2015.

Agradecimiento: A las familias del Centro de Psicología Infantil FOR.TE.A. por su participación y colaboración en este estudio. A todas las personas con trastornos del espectro autista. 


\section{Introduction}

People with autism present very varied functioning profiles despite sharing common alterations in typically disturbed development areas (reciprocal social interaction, language and communication, symbolization and behavior). These alterations have very diverse phenotypes in each person with ASD (Nazeer \& Ghaziuddin, 2012), varying as a function of age, intellectual capacity, associated pathologies, the effects of received treatment, the person's social environment, family involvement, etc. Therefore, many factors will determine how the symptoms manifest in each person with ASD. The important aspect is that early detection of these symptoms is decisive for their improvement (Crosland, Clarke, \& Dunlap, 2012; Granpeesheh, Dixon, Tarbox, Kaplan, \& Wilke, 2009) because thereby, disruptive behaviors decrease and functional skills improve (Rogers \& Vismara, 2008). However, there is an obvious increase of ASD in young children (Fortea, Escandell, \& Castro, 2013a; Nygren et al., 2012), which confirms earlier tendencies in countries like the United States (Centers for Disease Control and Prevention, 2009), Canada (Baird et al., 2006) or Norway (Kogan et al., 2009). These high prevalences directly affect the need for early intervention (ET) and the design of effective programs (Fombonne, 2009) because of the direct correlation between ET and a positive prognosis (Schertz, Baker, Hurwitz, \& Benner, 2011). The last authors also indicate the need to intervene in natural and inclusive settings and to focus on pre-verbal behaviors, which are the basis for the development of higher competences. It has also been confirmed that intellectual capacity improves in cases where ET was implemented (Campbell \& Figueroa, 2001; Canal et al., 2006; Ramey \& Ramey, 1998; Ruiz \& Martin, 2009). Other ET programs achieve improvements in adaptive behavioral functioning and language, as well as decreases in the parents' stress and improvement of their perceptions of their own abilities (Reed et al., 2013).

When parents receive the diagnosis of their child's autism, they must not only face this fact, they must also choose a treatment from the large variety of existing methods (Miller, Schreck, Mulick, \& Butter, 2012), with or without underlying scientific support. Despite the fact that there are scientifically supported methods, parents continue to resort to methods with scarce validity, without the guarantee of research, and involving expensive, long, and in many cases, dangerous interventions (Matson, Adams, Williams, \& Rieske, 2013). The factors influencing the parents' decision about what method to follow are usually the recommendations of others, practical issues (availability, accessibility, cost, time required, the child's needs, and compatibility with other activities...), effectiveness of the intervention, 
and proven scientific evidence (Carlon, Carter, \& Stephenson, 2013). There is currently no agreement among researchers to defend a specific early intervention model versus another model, due to the heterogeneity of children with autism and their families (Howlin, Magiati, \& Charman, 2009; Ospina et al., 2008). However, they do agree that these children should receive treatment, the sooner, the better.

In this study, we propose an intervention based on the following methodologies: Early Intensive Behavioral Interventions (EIBI), the Early Start Denver Model (DENVER; Dawson et al., 2010), TEACCH (Mesibov, Shea, \& Schopler, 2005), and interventions focusing on communication, such as the Picture Exchange Communication System (PECS, Bondy \& Frost, 1994), the Total Communication Program (Schaeffer, Musil, \& Kollinzas, 1980), the Picture Communication System (PCS; Johnson, 1981), as well as training the parents. All these intervention models have shown their efficacy and will be described below.

As with the applied behavioral analysis (ABA) methodology (Lovaas, 1993), many investigations support the efficacy of EIBI (Eldevik et al., 2009) and recommend its application (Hayward, Eikeseth, Gale, \& Morgan, 2009) because it improves the intelligence quotient, adaptive behavior (Peters-Scheffer, Didden, Korzilius, \& Sturmey, 2011) and global functioning in small children (Eikeseth, 2009).

The Denver model (Rogers \& Dawson, 2010) is an ET model that integrates ABA with a relational-based approach. In this model, the children play an active role in the construction of their mental world, with a great impact on their interpersonal, affective, motor, and sensory relations. This is an efficacious intervention model because it improves cognitive and adaptive behavioral capacities and reduces the severity of the ASD diagnosis, while underlining the importance of early detection and intervention in autism (Dawson et al., 2010).

TEACCH (Mesibov et al., 2005) is based on the spatial-temporal organization of different settings to make them more comprehensible and predictable, capitalizing on the strong points and interests of children with ASD and endorsing the use of spontaneous and functional communication. Various investigations confirm an increase in fine motor and visual skills, personal autonomy, improvement of adaptive behavior, and a decrease in parents' anxiousness (Mesibov \& Shea, 2010; Welterlin, Turner-Brown, Harris, Mesibov, \& Delmolino, 2012). An early intervention program based on the TEACCH methodology reported a statistically significant decrease in parents' stress as well as an increase in the children's expressive and receptive language (Braiden, McDaniel, McCrudden, Janes, \& Crozier, 2012). 
The prioritization of the development of spontaneous and functional communicative skills should be inherent in every intervention program, as well as inviting the parents to participate in the setting of goals (Lord \& Bishop, 2010; Rogers \& Vismara, 2008). Hence, and taking into account that people with ASD prefer the visual information processing channel, we decided to use augmentative communication systems that combine spoken words with visual support (signs, pictograms, and photographs), like the Total Communication Program (Schaeffer et al., 1980), the PCS (Johnson, 1981), and the PECS (Bondy \& Frost, 1994).

With regard to family participation in the intervention, various studies show that when parents take on their educational responsibility in the program, they are capable of promoting many positive changes at home and in their lives, fostering children's learning and development (Panerai et al., 2009) as well as expressing a high level of satisfaction with the program (Braiden et al., 2012). Therefore, we contemplate family participation throughout the entire CEIP.

Despite that the effects of EIBI seem strong and robust, no treatment, including this one, has been efficacious for all children with ASD (Reichow, 2012). Moreover, there seems to be a tendency to use not one, but various different models as a function of the characteristics and needs of children with ASD (Eldevik et al., 2009). Thus, the study of Callahan, Shukla-Mehta, Magee, and Wie (2010) reports that special education teachers, parents, and therapists observe that the combination of $\mathrm{ABA}$ and TEACCH favors the development of people with ASD.

\section{Method}

\section{Participants}

The sample (Table 1) is made up of 26 boys and 2 girls, aged between 17 and 74 months; 93\% of them were 38 months old or younger at the time of diagnosis and initiation of treatment. All are residents of Gran Canaria (Spain). The rest of them-two participantswere 44 and 74 months old, respectively, at initiation of treatment. The former child has Down's syndrome and ASD, and the latter has intellectual disability associated with ASD. None of them had received medication for the central symptoms of ASD. 
Table 1. Frequency of Children's Age (in Months) at Treatment Initiation

\begin{tabular}{ccccc}
\hline Age & Frequency & Percentage & $\begin{array}{c}\text { Valid } \\
\text { percentage }\end{array}$ & $\begin{array}{c}\text { Accumulated } \\
\text { percentage }\end{array}$ \\
\hline 17 & 2 & 7.1 & 7.1 & 7.1 \\
18 & 2 & 7.1 & 7.1 & 14.3 \\
19 & 1 & 3.6 & 3.6 & 17.9 \\
20 & 1 & 3.6 & 3.6 & 21.4 \\
21 & 1 & 3.6 & 3.6 & 25.0 \\
23 & 2 & 7.1 & 7.1 & 32.1 \\
24 & 1 & 3.6 & 3.6 & 35.7 \\
26 & 1 & 3.6 & 3.6 & 39.3 \\
27 & 2 & 7.1 & 7.1 & 46.4 \\
28 & 3 & 10.7 & 10.7 & 57.1 \\
29 & 1 & 3.6 & 3.6 & 60.7 \\
30 & 1 & 3.6 & 3.6 & 64.3 \\
31 & 4 & 14.3 & 14.3 & 78.6 \\
33 & 1 & 3.6 & 3.6 & 82.1 \\
35 & 1 & 3.6 & 3.6 & 85.7 \\
38 & 2 & 7.1 & 7.1 & 92.9 \\
44 & 1 & 3.6 & 3.6 & 96.4 \\
74 & 1 & 3.6 & 3.6 & 100.0 \\
Total & 28 & 100.0 & 100.0 & \\
\hline
\end{tabular}

They came to the Child Psychology Center, specialized in the diagnosis and treatment of ASD and behavioral disorders, because they did not speak or they had difficulties communicating, according to their parents' reports. Most of them were referred from pediatric consultations where the validated Spanish version of Canal et al. (2010) of the Modified Checklist for Autism in Toddlers (Robins, Fein, Barton, \& Green, 2001) was administered and the suspicion of ASD was proposed. They all underwent a process of diagnosis and were classified as autistic (according to the criteria of the Diagnostic and Statistical Manual of Mental Disorders-IV-TR, American Psychiatric Association, 2000). The Autism Diagnostic Interview-Revised (ADIR; Rutter, Le Couteur, \& Lord, 1994) and the Autism Diagnostic Observation Schedule (ADOS; Lord et al., 2000) were employed, administered by experts accredited in their use.

\section{Instruments}

To measure the efficacy of the CEIP, we created an ad hoc survey (Annex 1) that the parents completed in two stages: before and three months after initiating the intervention program. This survey is taken from a prior study (Fortea, Escandell, \& Castro, 2013b) that used the "Cuestionario para familias de personas con autismo" [Questionnaire for families of autistic 
people]. It is made up of 43 questions, the same as those used for the surveys carried out with relatives of people with autism in Spain, designed and assessed by the "Grupo de Estudio de los Trastornos del Espectro Autista" [Study Group of Autism Spectrum Disorders] (2003). It collects data about the needs of people with autism and their families with regard to diagnosis, care, and orientation in order to improve their quality of life. One of the open questions requested the families to name the first behaviors that made them suspect that something was wrong with their child's development and that led them to consult with professionals for a diagnosis. These behaviors are independently categorized by three expert observers according to the development areas that are altered in ASD (reciprocal social interaction, communication, and behavior) and which are tapped by the diagnostic instruments employed. Lastly, the questions were reduced to 10 items that make up the survey. Parents score the extent to which a behavior is present in their child on a 4-level frequency scale: never, sometimes, frequently, and always.

\section{Procedure}

After completing the diagnostic process, the children initiated the CEIP (Escandell \& Fortea, 2013) at the Child Psychology Center. The CEIP proposes individualized goals in four developmental areas: a) basic behavior and skills (with goals like increasing waiting times, focusing and maintaining attention on an activity, responding to simple and contextualized orders, extinguishing inadequate behaviors, increasing variety in food ingestion...), b) cognition and symbolization (developing the first functional and symbolic games, imitating simple motor models, performing hand-eye coordination games in an orderly and sequenced fashion, recognizing body schema...), c) language and communication (concurrently pointing and vocalizing, imitating sounds and syllables, receptive and expressive discrimination of yes-no with a function of acceptance-rejection using gestural and verbal modalities, promoting imitation of sounds and words, favoring the development of spontaneous oral speech...); and d) socio-emotional (developing circular games of reciprocal social interaction, fostering gestures of greeting, leave-taking, social kiss or smile, developing reference capacities, recognizing basic emotions in self and others, favoring the skills of social peer interaction, either self-initiated or in response to actions initiated by others...).

The application frequency of the CEIP varied from three to five 45-minute weekly sessions carried out by professional experts in ASD. In addition, the families attended a weekly 2-hour family school session so that the parents would understand the psychological functioning of their children, while learning adequate action strategies. Before initiating the 
program, the parents completed the first part of the survey (S1) and three months after initiating the CEIP, they completed the second part (S2) (Annex 1).

\section{Results}

The results revealed significant differences in all the items before and after the intervention. All the behaviors observed were sensitive to treatment, and significant improvements were obtained in all of them after the intervention (Table 2).

With regard to the relationships between the improvements found in the different areas assessed, strong positive correlations were observed (Table 3) between improvement in communication and improvement in expressive and receptive language; improvement in expressive language correlated with improvement in receptive language; improvement in social interaction correlated with improvement in emotional lability and play; improvement in play correlated with improvement in emotional lability and motor behavior and with a decrease in self-injury.

Table 2. Differences in pre-posttreatment means of the different behaviors assessed by parents

Related differences

\begin{tabular}{|c|c|c|c|c|c|c|c|c|}
\hline & $M$ & $S D$ & SEM & Upper & Lower & $T$ & $d f$ & $\begin{array}{l}p \text { (two- } \\
\text { tailed) }\end{array}$ \\
\hline $\begin{array}{l}\text { Altered social } \\
\text { interaction }\end{array}$ & 1.286 & .854 & .161 & .954 & 1.617 & 7.962 & 27 & .000 \\
\hline Altered gaze & 1.107 & .685 & .130 & .841 & 1.373 & 8.549 & 27 & .000 \\
\hline $\begin{array}{l}\text { Altered } \\
\text { communication }\end{array}$ & 1.643 & .951 & .180 & 1.274 & 2.012 & 9.139 & 27 & .000 \\
\hline $\begin{array}{l}\text { Altered } \\
\text { expressive } \\
\text { language }\end{array}$ & 1.321 & .819 & .155 & 1.004 & 1.639 & 8.538 & 27 & .000 \\
\hline $\begin{array}{l}\text { Altered } \\
\text { receptive } \\
\text { language }\end{array}$ & 1.250 & .887 & .168 & .906 & 1.594 & 7.456 & 27 & .000 \\
\hline $\begin{array}{l}\text { Emotional } \\
\text { lability }\end{array}$ & 1.107 & .786 & .149 & .802 & 1.412 & 7.454 & 27 & .000 \\
\hline $\begin{array}{l}\text { Altered motor } \\
\text { behavior }\end{array}$ & .750 & .799 & .151 & .440 & 1.060 & 4.965 & 27 & .000 \\
\hline Altered play & 1.214 & .917 & .173 & .859 & 1.570 & 7.005 & 27 & .000 \\
\hline Self-injuries & .429 & .790 & .149 & .122 & .735 & 2.870 & 27 & .008 \\
\hline $\begin{array}{l}\text { Sensitivity to } \\
\text { sensory stimuli }\end{array}$ & .714 & .713 & .135 & .438 & .991 & 5.303 & 27 & .000 \\
\hline
\end{tabular}


In view of these results, which confirmed significant improvements in all the areas assessed and the relationships between these improvements, we proposed to determine which items from the different diagnostic tests previously applied (before treatment) predict or are related either to more extensive improvement or to greater resistance to change after treatment.

Table 3. Correlations of the Posttreatment Improvements in the different Behaviors assessed by Parents

\begin{tabular}{|c|c|c|c|c|c|c|}
\hline & $\begin{array}{c}\text { Social } \\
\text { interaction }\end{array}$ & Communication & $\begin{array}{c}\text { Expressive } \\
\text { language }\end{array}$ & $\begin{array}{c}\text { Emotional } \\
\text { lability }\end{array}$ & $\begin{array}{c}\text { Motor } \\
\text { behavior }\end{array}$ & Play \\
\hline $\begin{array}{l}\text { Expressive } \\
\text { language }\end{array}$ & & $.676^{* *}$ & & & & \\
\hline $\begin{array}{l}\text { Receptive } \\
\text { language }\end{array}$ & & $.636 * *$ & $.650 * *$ & & & \\
\hline $\begin{array}{l}\text { Emotional } \\
\text { lability }\end{array}$ & $.449^{*}$ & & & & & \\
\hline $\begin{array}{l}\text { Play } \\
\text { Decrease }\end{array}$ & $.392 *$ & & & $.378 *$ & $.379 *$ & \\
\hline $\begin{array}{l}\text { of self- } \\
\text { injuries }\end{array}$ & & & & & & $.494 * *$ \\
\hline
\end{tabular}

Table 4 presents the correlations between improvement of the different behaviors observed and the partial scores of the diagnostic tests ADOS and ADIR. As can be observed, the greatest resistance to improvement in communication (Item 3) occurs in children with high scores in the "use of another person's body to communicate," with marked qualitative alteration in "reciprocal social interaction" in general, specifically, in "lack of shared enjoyment or pleasure" or altered behavior "nodding head for yes."

Altered expressive language (Item 4) is an objective behavior that is more difficult to improve in children with high scores in "lack of shared enjoyment or pleasure" or with few behaviors of "seeking to share their delight or enjoyment with others."

It is difficult to improve receptive language (Item 5) in children with "altered social smile, lack of "imaginative play with their peers," or lack of "friends," "lack of shared enjoyment or pleasure," few behaviors of "seeking to share their delight or pleasure with others," or presence of "limited interests."

Emotional lability (Item 6) barely improves in children with difficulties making "friends." 
Motor behaviors are especially prone to improvement (Item 7) in children with marked alterations in "play" in general and in "functional play with objects" in particular, in the "quality of social approaches," or who are "preoccupied with parts of objects or nonfunctional elements of materials." In contrast, children with high scores in "relative inability to initiate or maintain a conversation" in general, "verbalization social/talk," "reciprocal conversation," or who use "inverted pronouns" are especially resistant to change.

Play (Item 8) improves especially in children with high scores in "unusual visual contact." In contrast, it is more resistant to change in children with high scores in difficulties making "friends" or "nodding head for yes."

Sensitivity to sensory stimuli (Item 10) improves especially in children with high scores in "apparently compulsive adherence to routines or non-functional rituals" or in "verbal rituals." In contrast, this behavior change is reduced in children with altered behavior "Shaking head for no."

We did not take into account the correlations obtained among the improvements in the assessment survey items and the scores concerning age at the onset of the development alterations (section D of the ADIR) because many of these children were not yet 24 months old $(35.7 \%)$, and most of them were not even 33 months old $(82.1 \%)$. 
Table 4. Correlations between ADOS and ADIR and Posttreatment Improvements found in the different behaviors assessed by parents

\begin{tabular}{|c|c|c|c|c|c|c|c|c|c|c|}
\hline & & \multirow[b]{2}{*}{$\begin{array}{l}\text { Social } \\
\text { Interact } \\
\text { ion }\end{array}$} & \multirow[b]{2}{*}{$\begin{array}{l}\text { Doesn't } \\
\text { meet } \\
\text { gaze }\end{array}$} & \multirow[b]{2}{*}{$\begin{array}{c}\text { Scarce } \\
\text { Communicatio } \\
n\end{array}$} & \multirow[b]{2}{*}{$\begin{array}{c}\text { Lack/loss } \\
\text { of } \\
\text { Language }\end{array}$} & \multicolumn{2}{|c|}{ Alterations } & \multirow[b]{2}{*}{$\begin{array}{l}\text { Stereotyped } \\
\text { Movements }\end{array}$} & \multirow[b]{2}{*}{$\begin{array}{l}\text { Inappropriate } \\
\text { Use of Toys }\end{array}$} & \multirow[b]{2}{*}{$\begin{array}{c}\text { Self- } \\
\text { injuries }\end{array}$} \\
\hline & & & & & & $\begin{array}{c}\text { Low } \\
\text { Comprehens } \\
\text { ion }\end{array}$ & $\begin{array}{c}\text { Emotion } \\
\text { al } \\
\text { Lability }\end{array}$ & & & \\
\hline \multirow{11}{*}{ ADOS } & Use of other's body to communicate & & & $-.464^{*}$ & & & & & & \\
\hline & Unusual visual contact & & & & & & & & $.381^{*}$ & \\
\hline & Play in general & & & & & & & $.383^{*}$ & & \\
\hline & Functional play & & & & & & & $.375^{*}$ & & \\
\hline & Social interaction & & & $-.375^{*}$ & & & & & & \\
\hline & Social smile & & & & & $-.409 *$ & & & & \\
\hline & Imaginative play with peers & & & & & $-.400^{*}$ & & & & \\
\hline & Friends & & & & & $-.398 *$ & $-398^{*}$ & & $-.374 *$ & \\
\hline & Lack of shared enjoyment or pleasure & & & $-.390^{*}$ & $-.406^{*}$ & $-.422^{*}$ & & & & \\
\hline & $\begin{array}{l}\text { Seeks sharing delight and pleasure with } \\
\text { others }\end{array}$ & & & & $-.494 * *$ & $-.419^{*}$ & & & & \\
\hline & Quality of social approaches & & & & & & & $.393^{*}$ & & \\
\hline \multirow[t]{11}{*}{ ADIR } & Nodding head for yes & & & $-.380^{*}$ & & & & & $-.430^{*}$ & \\
\hline & Shaking head for no & & & & & & & & & \\
\hline & $\begin{array}{l}\text { Relative inability to initiate or maintain } \\
\text { a conversation }\end{array}$ & & & & & & & $-.496^{* *}$ & & \\
\hline & Social verbalization/talk & & & & & & & $-.492^{* *}$ & & \\
\hline & Reciprocal conversation & & & & & & & $-.499 * *$ & & \\
\hline & Inversion of pronouns & & & & & & & $-.393^{*}$ & & \\
\hline & Limited interests & & & & & $-.467^{*}$ & & & & \\
\hline & Apparently compulsive & & & & & & & & & \\
\hline & $\begin{array}{l}\text { Adherence to routines or non- } \\
\text { functional rituals } \\
\text { Verbal rituals } \\
\text { Preoccupation with parts of objects or } \\
\text { non-functional elements of materials }\end{array}$ & & & & & & & $.443^{*}$ & & \\
\hline & Age at which parents first noticed it & $-.393^{*}$ & $-.541^{* *}$ & & & & & & & $-.638^{* *}$ \\
\hline & Age at which abnormality was evident & & $-.390 *$ & & & & & & & \\
\hline
\end{tabular}




\section{Discussion}

Despite the existing literature on the effectiveness of different methodologies and strategies such as the EIBI (Granpeesheh et al., 2009; Matson, Tureck, Turygin, Beighley, \& Rieske, 2012; Reichow, 2012), the Denver Model (Dawson et al., 2010), TEACCH (Braiden, et al., 2012; Eikeseth, 2009; Mesibov \& Shea, 2010; Panerai et al., 2009; Virués-Ortega, Julio, \& Pastor-Barriuso, 2013; Welterlin et al., 2012), Augmentative Communication Systems (Boesch, Wendt, Subramanian, \& Hsu, 2013; Cummings, Carr, \& LeBlanc, 2012; Schaeffer et al., 1980; Schaeffer, Kollinzas, Musil, \& McDowell, 1977), and Intervention with Families (Roberts et al., 2011; Welterlin et al., 2012), the CEIP may be one of the few studies that contemplates the efficacy of the strategies belonging to different and varied methodologies. Each one of these methods taken separately have beneficial effects on concrete development areas but none of them has achieved clear advances in all the areas contemplated in the CEIP.

Although Granpeesheh et al. (2009) showed that the efficacy of the intervention decreases as the children grow older, as we did not analyze their effects separately, we cannot explain the advances obtained either by the early intervention or specifically by any of the methods and strategies. Moreover, one of the children was 74 months old at treatment initiation, and improvements were observed a few months later, as also occurred with another child who was 44 months old; both these children had intellectual disability associated with ASD. In spite of the fact that there were only two cases, we must consider the possibility that the CEIP may be efficacious in older children with cognitive deficits, a possibility that is open to future research with samples of these characteristics.

Of the items assessed by the parents, the greatest advances are observed in communication (Boesch et al., 2013; McGarrell, Healy, Leader, O’Connor, \& Kenny, 2009), followed by improvements in expressive and receptive language (Mesibov \& Shea, 2010; Peters-Scheffer et al., 2011; Virués-Ortega et al., 2013) and in play (Solomon, Necheles, Ferch, \& Bruckman, 2007), . This is probably related to progress in social interaction (Casenhiser, Shanker, \& Stieben, 2013), and all of this is probably related to age at initiation of intervention, as noted by Rogers and Vismara (2008) and Schertz et al. (2011).

As the children acquire an efficacious communication system, behavioral problems decrease (McGarrell et al., 2009; Peters-Scheffer et al., 2011). If communication improves, the children are provided with an efficacious instrument, and their disruptive behavior decreases considerably. Therefore, we must train them as soon as possible in the use of effective communication systems and consider the use of such systems in all the early intervention programs. 
If the children's capacity for social interaction increases significantly and, in general, their behavior is more adaptive, the parents feel better and are in optimal conditions to accompany their children in their development (Reed et al., 2013). On the one hand, if the parents' perception of their abilities improves (Tonge, Brereton, Kiomal, Mackinnon, \& Rinehart, 2014), the burden of stress decreases as does the probability of future behavior problems in the children (Osborne, McHugh, Saunders, \& Reed, 2008). It would be interesting to determine the parents' emotional status before and after the intervention and to confirm the results not only in the children but also in the parents, contemplating the possibility of adjusting the frequency of the family school sessions.

Just as the presence of a child with autism involves severe economic problems for the family (Dababnah, Parish, Turner, \& Hooper, 2011), effective early intervention programs should directly affect their economy because if the children improve, they will need less support in the future, thus reducing the cost of treatment. The CEIP requires daily dedication by the child and the family, with direct intervention by the professional of no longer than one hour per day (except for the family school), which implies a reduction of the cost of treatment from the start, and making it accessible to many families.

However, if we relate high scores in certain items of the ADOS and the ADIR to a greater resistance to change in some behaviors, we could reinforce the intervention in those behaviors in these high-scoring children.

Although there is a consensus that more research is needed to show positive results of interventions, and that controlled random trial (CRTs) are the most robust way of doing this, performing CRTs of intervention-based learning entail important associated methodological and ethical difficulties (Roberts et al., 2011).

It would be very complicated to control all the variables that can affect the progress of children with ASD (development areas, socialization settings, the involved professionals, diverse methodologies). The control of these variables would favor the development of integral, individualized, and reliable treatment programs (Gould, Dixon, Najdowski, Smith, \& Tarbox, 2011).

Summing up, the above results show the efficacy of the CEIP, especially with regard to the improvements in the children's adaptive behavior and social communication, important aspects that predict future performance and success. The results of this study provide useful information to help families decide which pathway to follow when choosing the type of intervention that best matches their child and their socio-familiar setting. 
In spite of the significant differences before and after the intervention and our conclusion that all the observed behaviors are sensitive to treatment, we should be cautious and continue to observe the evolution of these children and compare them in future longitudinal studies.

\section{References}

American Psychiatric Association (2000). Diagnostic and statistical manual of mental disorders-IV-TR. Washington, DC: Author.

Baird, G., Simonoff, E., Pickles, A., Chandler, S., Loucas, T, Meldrum, D., \& Charman T. (2006). Prevalence of disorders of the autism spectrum in a population cohort of children in South Thames: the Special Needs and Autism Project (SNAP). Lancet, $368,210-215$.

Boesch, M. C., Wendt, O., Subramanian, A., \& Hsu, N. (2013). Comparative efficacy of the Picture Exchange Communication System (PECS) versus a speech-generating device: Effects on requesting skills. Research in Autism Spectrum Disorders, 7, 480-493.

Bondy, A., \& Frost, L. (1994). The Picture Exchange Communication System. Focus on Autistic Behavior, 16, 123-128.

Braiden, H. J., McDaniel, B., McCrudden, E., Janes, M., \& Crozier, B. (2012). A practicebased evaluation of Barnardo's forward steps early intervention programme for children diagnosed with autism. Child Care in Practice, 18(3), 227-242.

Callahan, K., Shukla-Mehta, S., Magee, S., \& Wie, M. (2010). ABA versus TEACCH: The case for defining and validating comprehensive treatment models in autism. Journal of Autism and Developmental Disorders, 40, 74-88.

Campbell, O. A., \& Figueroa, A. S. (2001). Impacto del autismo en la familia. La percepción de los padres. Archivos Neurociencias, 1(6), 6-4.

Canal, R., García, P., Martín, M. V., Santos, J., Guisuraga, Z., Herráez, L., .. Posada, M. (2010). Modified Checklist for Autism in Toddlers: Cross-Cultural adaptation and validation in Spain. Journal of Autism and Developmental Disorders, 41, 1342-1351. doi: 10.1007/s10803-010-1163-Z

Canal, R., García, P., Touriño, E., Santos, J., Martín, M. V., Ferrari, M. J.,... Posada, M. (2006). La detección precoz del autism. Intervención Psicosocial, 15(1), 29-47.

Carlon, S., Carter, M., \& Stephenson, J. (2013). A review of declared factors identified by parents of children with autism spectrum disorders (ASD) in making intervention decisions. Research in Autism Spectrum Disorders, 7, 369-381. 
Casenhiser, D. M., Shanker, S. G., \& Stieben, J. (2013). Learning through interaction in children with autism: Preliminary data from a social-communication-based intervention. Autism, 17(2) 220-241

Centers for Disease Control and Prevention (2009). Prevalence of autism spectrum disorders -Autism and Developmental Disabilities Monitoring Network. Atlanta, GA: Author.

Crosland, K. A., Clarke, S., \& Dunlap, G. (2012). A trend analysis of participant and setting characteristics in autism intervention research. Focus on Autism and Other Developmental Disabilities, 28(3) 159-165.

Cummings, A. R., Carr, J., \& LeBlanc, L. A. (2012). Experimental evaluation of the training structure of the Picture Exchange Communication System (PECS). Research in Autism Spectrum Disorders, 6, 32-45.

Dababnah, S., Parish, S., Turner, L., \& Hooper, S. (2011). Early screening for autism spectrum disorders: A primer for social work practice. Children and Youth Services Review, 33, 265-273.

Dawson, G., Rogers, S., Munson, J., Smith, M., Winter, J., Greenson, J.,...Varley, J. (2010). Randomized, controlled trial of an intervention for toddlers with autism: The Early Start Denver Model. Pediatrics, 125, 17-24.

Eikeseth, S. (2009). Outcome of comprehensive psycho-educational interventions for young children with autism. Research in Developmental Disabilities, 30, 158-178.

Eldevik, S., Hastings, R.P., Hughes, J. C., Jahr, E., Eikeseth, S., \& Cross, S. (2009). Meta -analysis of early intensive behavioral intervention for children with autism. Journal of Clinical Child \& Adolescent Psychology, 38(3), 439-450.

Escandell, M. O., \& Fortea, M. S. (2013). Programa de intervención temprana en un niño con trastorno del espectro autista. Proceedings of the VI International Congress and XI National Congress of Clinical Psychology. Asociación Española de Psicología Conductual (AEPC): Santiago de Compostela (Spain).

Fombonne, E. (2009). Epidemiology of pervasive developmental disorders. Pediatric Research, 65, 591-598.

Fortea, M. S., Escandell, M. O., \& Castro, J. J. (2013a). Estimación de la prevalencia de los trastornos del espectro autista en Canarias. Anales de Pediatría, 79, 352-359.

Fortea, M. S., Escandell, M. O., \& Castro, J. J. (2013b). Detección temprana del autismo: profesionales implicados. Revista Española de Salud Pública, 87, 191-199. 
Gould, E., Dixon, D. R., Najdowski, A. C., Smith, M. N., \& Tarbox, J. (2011). A review of assessments for determining the content of early intensive behavioral intervention programs for autism spectrum disorders. Research in Autism Spectrum Disorders, 5, 990-1002.

Granpeesheh, D., Dixon, D. R., Tarbox, J., Kaplan, A. M., \& Wilke, A. U. (2009). The effects of age and treatment intensity on behavioral intervention outcomes for children with autism spectrum disorders. Research in Autism Spectrum Disorders, 3, 1014-1022.

Grupo de Estudio de los Trastornos del Espectro Autista (2003). Informe sobre la valoración de las familias del proceso diagnóstico. Retrieved from http://iier.isciii.es/autismo/pdf/aut_inv.pdf.

Hayward, D., Eikeseth, S., Gale, C., \& Morgan, S. (2009). Assessing progress during treatment for young children with autism receiving intensive behavioral interventions. Autism, 13, 613-633.

Howlin, P., Magiati, I., \& Charman, T. (2009). Systematic review of early intensive behavioural interventions for children with autism. American Journal of Intellectual and Developmental Disabilities, 114, 23-41.

Johnson, R. (1981). The picture communication symbols combination. Solana Beach, CA: Mayer-Johnson.

Kogan, M. D., Blumberg, S. J., Schieve, L. A., Boyle, C. A., Perrin, J. M., Ghandour, R.,... Van Dyck, P. C. (2009). Prevalence of parent-reported diagnosis of autism spectrum disorder among children in the US, 2007. Pediatrics, 5(124), 1395-1403.

Lord, C., \& Bishop, S. L. (2010). Autism spectrum disorders diagnosis, prevalence, and services for children and families. Social Policy Report, 24, 1-27.

Lovaas, O. I. (1993). The development of a treatment-research project for developmentally disabled and autistic children. Journal of Applied Behavior Analysis, 26(4), 617-630.

Lord, C., Risi, S., Lambrecht,L., Cook, E. H., Jr., Leventhal,B. L., DiLavore, P. C., Pickles, A., \& Rutter. M. (2000). The Autism Diagnostic Observation Schedule-Generic: A standard measure of social and communication deficits associated with the spectrum of autism. Journal of Autism and Developmental Disorders, 30(3), 205-223.

Matson, J. L., Adams, H. L. Williams, W., \& Rieske, R. D. (2013). Why are there so many unsubstantiated treatments in autism? Research in Autism Spectrum Disorders, 7, 466-474. 
Matson, J. L., Tureck, K., Turygin, N., Beighley, J., \& Rieske, R. (2012). Trends and topics in early intensive behavioral interventions for toddlers with autism. Research in Autism Spectrum Disorders, 6, 1412-1417.

McGarrell, M., Healy, O., Leader, G., O’Connor, J., \& Kenny, N. (2009). Six reports of children with autism spectrum disorder following intensive behavioral intervention using the Preschool Inventory of Repertoires for Kindergarten (PIRK). Research in Autism Spectrum Disorders, 3, 767-782.

Mesibov, G. B., \& Shea, V. (2010). The TEACCH Program in the era of evidence-based practice. Journal of Autism and Developmental Disorders, 40, 570-579.

Mesibov, G. B., Shea, V., \& Schopler, E. (Eds.). (2005). The TEACCH approach to autism spectrum disorders. New York: Springer.

Miller, V. A., Schreck, K. A. Mulick, J. A., \& Butter, E. (2012). Factors related to parents' choices of treatments for their children with autism spectrum disorders. Research in Autism Spectrum Disorders, 6, 87-95.

Nazeer A., \& Ghaziuddin M. (2012). Autism spectrum disorders: Clinical features and diagnosis. Pediatric Clinics of North America, 59 (1), 19-25.

Nygren, G., Sandberg, E., Gillstedt, F., Ekeroth, F., Arvidsson, T., \& Gillberg, C. (2012). A new screening programme for autism in a general population of Swedish toddlers. Research in Developmental Disabilities, 33, 1200-1210.

Osborne, L. A., McHugh, L., Saunders, J., \& Reed, P. (2008). The effect of parenting behaviors on subsequent child behavior problems in austictic spectrum condition. Research in Autism Spectrum Disorders, 2, 249-263.

Ospina, M. B., Seida, J. K., Clark, B., Karkhaneh, M., Hartling, L., Tjosvold, L.,... Smith, V. (2008). Behavioural and developmental interventions for autism spectrum disorder: A clinical systematic review. PLOS ONE, 3, 1-32.

Panerai, S., Zingale, M., Trubia, G., Finocchiaro, M., Zuccarello, R., Ferri, R., \& Elia, M. (2009). Special education versus inclusive education: The role of the TEACCH program. Journal of Autism and Developmental Disorders, 39, 874-882.

Peters-Scheffer, N., Didden, R., Korzilius, H., \& Sturmey, P. (2011). A meta-analytic study on the effectiveness of comprehensive ABA-based early intervention programs for children with autism spectrum disorders. Research in Autism Spectrum Disorders, 5, $60-69$.

Ramey, C. T., \& Ramey, S. L. (1998). Early intervention and early experience. American Psychologist, 53, 109-120. 
Reed, P., Osborne, L. A., Makrygianni, M., Waddington, E., Etherington, A., \& Gainsborough, J. (2013). Evaluation of the Barnet Early Autism Model (BEAM) teaching intervention programme in a 'real world' setting. Research in Autism Spectrum Disorders, 7, 631-638.

Reichow, B. (2012). Overview of meta-analyses on early intensive behavioral intervention for young children with autism spectrum disorders. Journal of Autism and Developmental Disorders, 42, 512-520.

Roberts, J., Williams, K., Carter, M., Evans, D., Parmenter, T., Silove, N., ...Warren, A. (2011). A randomised controlled trial of two early intervention programs for young children with autism: Centre-based with parent program and home-based. Research in Autism Spectrum Disorders, 5, 1553-1566.

Robins, D.L., Fein, D., Barton, M.L., \& Green, J.A. (2001). The modified checklist for autism in toddlers: An initial study investigating the early detection of autism and pervasive developmental disorders. Journal of Autism and Developmental Disorders, $31,131-144$.

Rogers, S. J., \& Dawson, G. (2010). Early Start Denver Model for young children with autism. Promoting language, learning and engagement. New York: Guilford Press.

Rogers S. J., \& Vismara, L. A (2008). Evidence-based comprehensive treatments for early autism. Journal of Clinical Child \& Adolescent Psychology, 37, 8-38.

Rutter, M., Le Couteur, A., \& Lord, C. (1994). Autism Diagnostic Interview-Revised: A revised version of a diagnostic interview for caregivers of individuals with posible pervasive developmental disorders. Journal of Autism and Developmental Disorders, 24(3), 659-685.

Ruiz, J., \& Martin, P. (2009). La prevalencia de los trastornos del espectro autista no ha aumentado pero su diagnóstico se realiza en edades más precoces. Evidencias en Pediatría, 5, 1-14.

Schaeffer, B., Kollinzas, G., Musil, A. \& McDowell, P. (1977). Spontaneous verbal language for autistic children through signed speech. Sign Language Studies, 17, 287-328.

Schaeffer, B., Musil, A., \& Kollinzas, G. (1980). Total Communication: A signed speech program for non-verbal children. Champaign, IL: Research Press.

Schertz, H. H., Baker, C., Hurwitz, S., \& Benner, L. (2011). Principles of early intervention reflected in toddler research in autism spectrum disorders. Topics in Early Childhood Special Education, 31, 3-21. 
Solomon, R., Necheles, J., Ferch, C., \& Bruckman, D. (2007). Pilot study of a parent training program for young children with autism: The PLAY Project Home Consultation program. Autism, 11(3) 205-224.

Tonge1, B., Brereton, A., Kiomal, M., Mackinnon, A., \& Rinehart, N. J. (2014). A randomised group comparison controlled trial of 'preschoolers with autism': A parent education and skills training intervention for young children with autistic disorder. Autism, 18(2) 166-177.

Virués-Ortega, J., Julio, F. M. \& Pastor-Barriuso, R. (2013). The TEACCH program for children and adults with autism: A meta-analysis of intervention studies. Clinical Psychology Review, 33, 940-1417.

Welterlin, A., Turner-Brown, L. M., Harris, S., Mesibov, G., \& Delmolino, L. (2012). The home TEACCHing program for toddlers with autism. Journal of Autism and Developmental Disorders, 42, 1827-1835. 
Annex 1. Pre- and Posttreatment Assessment Survey to be completed by the Parents

\begin{tabular}{|c|c|c|c|c|}
\hline BEHAVIORS ASSESSED & NEVER & SOMETIMES & FREQUENTLY & ALWAYS \\
\hline $\begin{array}{l}\text { Altered social interaction: } \\
\text { distracted, absent, in his/her } \\
\text { own world, not interested in } \\
\text { other children, does not } \\
\text { give kisses, does not smile, } \\
\text { withdrawn, solitary, } \\
\text { independent, plays alone }\end{array}$ & & & & \\
\hline $\begin{array}{l}\text { 2. Altered gaze: Does not } \\
\text { maintain gaze }\end{array}$ & & & & \\
\hline $\begin{array}{l}\text { 3. Altered communication: } \\
\text { scarce communication, does } \\
\text { not point, does not ask, } \\
\text { does not request, does not } \\
\text { gesture, indicates needs by } \\
\text { taking you by the hand }\end{array}$ & & & & \\
\hline $\begin{array}{ll}4 . & \text { Altered expressive } \\
\text { language: loss or lack of } \\
\text { language, little vocabulary, } \\
\text { echolalia }\end{array}$ & & & & \\
\hline $\begin{array}{l}\text { 5. Altered receptive language: } \\
\text { Low comprehension: does } \\
\text { not respond to orders, does } \\
\text { not respond when called, } \\
\text { does not respond to his/her } \\
\text { name, pays no attention, } \\
\text { seems deaf }\end{array}$ & & & & \\
\hline $\begin{array}{ll}6 . & \text { Emotional lability: crying } \\
\text { intensely, unmotivated } \\
\text { tantrums, excessive crying, } \\
\text { fears, hesitations, laughs for } \\
\text { no reason }\end{array}$ & & & & \\
\hline $\begin{array}{l}\text { 7. Altered motor behavior: } \\
\text { Stereotyped movements, } \\
\text { flapping, mannerisms, } \\
\text { rocking, tiptoeing, motor } \\
\text { clumsiness, racing, } \\
\text { jumping, low/high muscle } \\
\text { tone, too quiet or excessive } \\
\text { activity }\end{array}$ & & & & \\
\hline $\begin{array}{l}\text { 8. Altered play: Inappropriate } \\
\text { use of toys (rotates them, } \\
\text { lines them up, throws them, } \\
\text { tears papers...), fixations, } \\
\text { arranging, collecting things }\end{array}$ & & & & \\
\hline $\begin{array}{l}\text { 9. Self-injuries: hits self on } \\
\text { head, bites self }\end{array}$ & & & & \\
\hline $\begin{array}{l}\text { 10. Sensitivity to sensory } \\
\text { stimuli: Very sensitive to } \\
\text { sounds, smells, textures, } \\
\text { rejects physical contact }\end{array}$ & & & & \\
\hline
\end{tabular}

